\title{
2 Regional economic communities and peacebuilding in Africa
}

\author{
Analysis of legal framework and concerns for \\ international law
}

Olugbemi Jaiyebo and Victor Adetula

\section{Introduction}

The original mandates of African regional economic communities (RECs) were tilted towards economic objectives with less attention to peacebuilding. However, the hardcore purpose of the RECs could only be realised if the regions were peaceful and secure. Prevalence of violent conflicts in Africa, particularly since the end of the Cold War, as well as growing awareness about peace as a precondition for development, motivated African states to expand the mandates of the RECs to include responsibility for ensuring regional peace and security. Also, the changes and developments in the international system, such as the seeming retreat of the great powers from active involvement outside their immediate regions, played a crucial role. An apparent shift in the strategic interests of the global North away from Africa reinforced the necessity for African solutions to African problems.

RECs now function as part of the continent-wide peace and security architecture that is managed essentially by the African Union (AU) within the United Nations' mandate to promote global peace and security. This function spans the entire peace process spectrum from conflict prevention to peacebuilding, pertaining to matters such as effective delivery of public goods to citizens and measures to achieve sustainable peace between parties in conflicts that ordinarily should be the responsibility of the state. Adherence to international law is a precondition for generating political and moral legitimacy. Consequently, the involvement of external actors in the domestic affairs of the conflict-affected countries requires definite legal frameworks and clear normative standards. What are the legal frameworks for the new roles of RECs, and what is the extent of compliance with international law? With a focus on the Economic Community of West African States (ECOWAS) and the Intergovernmental Authority on Development (IGAD), this chapter examines the legal frameworks through which the African Union and African RECs engage the complexities of peacebuilding. Additionally, the chapter demonstrates how the existing legal infrastructure puts the RECs at an advantage over the UN and other external actors in the areas of right of access to the theatre of conflict, enforcement of ceasefire agreements, discipline, and oversight of international personnel. The chapter concludes that the future of 
peacebuilding in Africa depends on the transformation of Africans RECs into functional supranational institutions.

\section{Frameworks for continental and regional interventions}

When initially incorporated into the lexicon of international law, "peacebuilding" encapsulated actions supporting processes and structures that strengthen and consolidate peace to avoid a relapse into conflict (United Nations, 1992). Peacebuilding is closely associated with the purpose of the UN to maintain global peace, which prioritises conflict prevention (United Nations, 2015). Attempts to harmonise the UN peacebuilding components gave rise to the idea of a peacebuilding architecture for the UN. Eventually, the UN Peacebuilding Commission (PBC) was created by concurrent resolutions of the Security Council and General Assembly to coordinate and reinforce the UN peacebuilding architecture. ${ }^{1}$

The African Peace and Security Architecture (APSA) is the AU's primary mechanism for promoting peace and security. APSA has the mandate to promote and develop strong partnerships for peace and security with the AU, the United Nations, and other international organisations. Vital elements of APSA include the Peace and Security Council (PSC), the Continental Early Warning System (CEWS), the African Standby Force (ASF), the Panel of the Wise (PoW), and the Peace Fund. The PSC serves as a collective security and early-warning arrangement to facilitate timely and efficient responses to conflicts and crises in Africa. Its mandate includes the development of policies and action required to ensure that any external initiative in the field of peace and security on the continent takes place within the framework of the Union's objectives and priorities.

The PSC promulgated the African Union Policy on Post-Conflict Reconstruction and Development (PCRD) to guide improvements in the timeliness, effectiveness, and coordination of activities in post-conflict countries, and to lay the foundation for social justice and sustainable peace. The PCRD is a product of wide consultation that involved all African RECs and their state members. It acknowledges the dependence of its successful implementation on the active engagement of regional groupings and their institutions and envisages regional guidelines for its implementation and regional focal points to support its processes.

The PCRD is a tool to: a) consolidate peace and prevent relapses into violence; b) address the root causes of conflict; c) encourage and fast-track the planning and implementation of reconstruction activities; and d) enhance complementarities and coordination between and among diverse actors engaged in PCRD processes. ${ }^{2}$ The end state of the PCRD is one where peace, law, and order prevail; the humanitarian situation has stabilised and populations are able to meet their basic needs; political mechanisms and institutions have been established to prevent and manage conflict through peaceful means and to institutionalise equitable participation in political and socioeconomic life; and access to justice is ensured and human rights are guaranteed.

Paragraph 4 (b) of the African Union's PCRD states that the intervention process commences when the AU mechanisms, in line with the relevant provisions 
of the Constitutive Act of the African Union, determine that a situation warrants attention, or when parties to a conflict have demonstrated the political will to resolve differences through political negotiation, or have ceased hostilities, or have signed a peace agreement. The Assembly of Heads of State and Government of the African Union gave official recognition to eight sub-regional economic communities: the Arab Maghreb Union (AMU); the Community of SahelSaharan States (CEN-SAD); the Common Market for Eastern and Southern Africa (COMESA); the East African Community (EAC); the Economic Community of Central African States (ECCAS); the Economic Community of West African States (ECOWAS); the Intergovernmental Authority on Development (IGAD); and the Southern African Development Community (SADC). ${ }^{3}$ The peace and security infrastructure of the AU has continental application and each of the eight RECs has endeavoured to align the contents and provisions of their legal frameworks with the AU's framework. ${ }^{4}$

The ECOWAS Conflict Prevention Framework (ECPF) is the platform for peacebuilding in the ECOWAS region. ${ }^{5}$ The ECPF is a

comprehensive operational conflict prevention and peacebuilding strategy that enables the ECOWAS system and member states to draw upon human and financial resources at the regional (including civil society and the private sector) and international levels in their efforts to creatively transform conflict.

(ECOWAS, 2008, Article 7)

It places primary responsibility for peace and security on ECOWAS member states (ECOWAS, 2008, Preamble). It comprises 14 components that span a chain of initiatives designed to strengthen human security and incorporate conflict prevention activities (operational and structural), as well as aspects of peacebuilding (ECOWAS Conflict Prevention Framework, para. 42). The 14 components are early-warning; preventive diplomacy; democracy and political governance; human rights and the rule of law; media; natural resource governance; cross-border initiatives; security governance; practical disarmament; women, peace, and security; youth empowerment; the ECOWAS Standby Force (ESF); humanitarian assistance; and peace education (the Culture of Peace). ${ }^{6}$

ECOWAS has embarked on several peace initiatives since the ECPF came into effect, without any reference to the application or implementation of the framework. For example, ECOWAS recognises that the increasing incidence of clashes between farmers and pastoralists, rural banditry, electoral violence, and ethnic and religious violence in Côte d'Ivoire, Burkina Faso, Niger, Nigeria, and Mali are matters of urgent concern that require preventive interventions (ECOWAS, 2016). However, there is no record or at best very little evidence of ECOWAS's involvement at the level of mediation or active negotiation or physical deployment, for instance, in conflicts in Nigeria's Niger Delta region, northern Ghana, the Tuareg uprising in Niger, or the separatist agitations in the Casamance region in Senegal. These problem areas are rationalised as internal affairs of member 
states, thereby revealing the weak commitment of ECOWAS member states to the normative elements of human security enshrined in the ECPF (Ismail, 2011).

The supranational status of ECOWAS integrates the ECPF into the laws of ECOWAS member states and therefore has the potential to resolve the contradictions inherent in the interface of peacebuilding and sovereignty. The ECPF incorporates the Protocol Relating to the Mechanism for Conflict Prevention, Management, Resolution, Peacekeeping, and Security (1999), and the Protocol on Democracy and Good Governance (2001). "Without prejudice to other regional and international legal instruments, the Mechanism and the Supplementary Protocol on Democracy and Good Governance provide the principal basis and justification for the ECPF" (ECOWAS Conflict Prevention Framework, paras 36-39). Article 53 of the Protocol Relating to the Mechanism for Conflict Prevention, Management, Resolution, Peacekeeping, and Security abrogated incompatible provisions of the 1981 ECOWAS Protocol relating to Mutual Assistance in Defence and the 1978 Protocol on Non-Aggression. The ECPF resolved, at least theoretically, the contention between regime security and human security in favour of the latter, thereby negating the propositions that the defence and military protocols were mere "regime protection" strategies to serve the interests of ECOWAS leaders and "insure" them against external and internal security threats (Francis, 2009).

ECOWAS is imbued with the necessary supranational powers (acting on behalf of and in conjunction with member states, the AU, and the UN), as well as the legitimacy to intervene to protect human security in three distinct ways, namely:

a. The Responsibility to prevent - actions taken to address the direct and root causes of conflicts that put populations at risk.

b. The Responsibility to react - actions taken in response to grave and compelling humanitarian disasters.

c. The Responsibility to rebuild - actions taken to ensure recovery, reconstruction, rehabilitation, and reconciliation in the aftermath of violent conflicts, humanitarian or natural disasters.

(ECOWAS, 2008)

In their search for a mandate and legitimacy to intervene to protect human security, the drafters of the ECPF took refuge in "moral obligations" that are "beyond legal instruments and guidelines." The regulation should have equipped the moral imperatives with legality and transitioned morality to law. Predicating the mandate and legitimacy on morals rather than law undermines the very legitimacy the ECPF seeks to establish. ECOWAS's ability to generate consensus on its moral imperatives would have added momentum to the process of recognising Responsibility to Protect (R2P) as a legal duty of member states in the West African sub-region. R2P adjusts state sovereignty by declaring that for a state's sovereignty to be respected, the state must demonstrate responsibility to its citizens. A logical consequence is that interpretations of laws of occupation must be revised. On one hand, international law continues to presume the 
inappropriateness in all circumstances of coercive use of force to effect political change in another state; while on the other, there is evidence that where the use of force does occur, there is an emerging obligation to intervene and contribute to reconstruction (Arcila, 2007).

IGAD has the primary task of coordinating efforts to address regional resource issues. It was formed in 1996 to replace the Intergovernmental Authority on Drought and Development (IGADD). ${ }^{7}$ Its membership consists of six countries: Djibouti, Eritrea, Ethiopia, Kenya, Sudan, and Uganda. In Article 6A of the "Agreement Establishing the Intergovernmental Authority on Development" (IGAD Agreement), there is a solemn reaffirmation of the principles of non-interference in the internal affairs of member states, the peaceful settlement of interand intra-state conflicts through dialogue, and maintenance of regional peace, stability, and security. The principles in Article 6 of the IGAD Agreement are patterned after the OAU model in vogue during the Cold War era. The IGAD principles of non-interference and resolution of inter- and intra-state conflicts only through dialogue stand in conflict with the AU Constitutive Act which is designed to meet contemporary challenges of peace and security on the African continent. The Horn of Africa is bedevilled by serious inter- and intrastate conflicts. The IGAD Secretariat established a peace and security division and, in 2003, the IGAD Heads of State tasked the Secretariat with developing a comprehensive peace and security strategy.

In April 2005, IGAD adopted the memorandum of understanding and budget for the establishment of the Eastern Africa Standby Brigade (EASBRIG). IGAD is confronted with the problem of lack of funding. None of the member states is rich enough to provide support in the way that Nigeria supported the operations of the ECOWAS Ceasefire Monitoring Group (ECOMOG) in Liberia and Sierra Leone. Hence, the accomplishments of IGAD have been marginal compared with either the ECOWAS or the Southern African Development Community (SADC). Notwithstanding its challenges, IGAD has been engaged in complex reconciliation work in the region and cooperates closely with APSA.

The SADC's security infrastructure is provided for in the Protocol on Politics, Defence, and Security. The Mutual Defence Pact (MDP) provides a framework for defence cooperation and lays a foundation for establishing a security community. In response to the African Union's efforts to establish an African Peace and Security Architecture (APSA), the SADC has established a standby brigade (SADCBRIG) with policing (SADCPOL) and civilian components. The SADCBRIG is designed with capabilities to rapidly undertake the following types of operations: observation missions, peacekeeping and peacebuilding including complex multidimensional peace operations, peace enforcement, robust peace support operations, and humanitarian interventions in grave circumstances. The brigade was formally launched, and troop requirements have been met, and they have agreed on a common peace support doctrine. A permanent planning element (PLANELM) has been established at the SADC Secretariat for coordination purposes with a Regional Peacekeeping Training Centre (RPTC) (Malebang, 2012). 
The strengthening of peace, security, stability, and good governance is specified in the aims and objectives of COMESA. ${ }^{8}$ In 1999, COMESA Authority mandated its Ministers of Foreign Affairs to meet annually to deliberate on matters regarding the promotion of peace, security, and stability in the regional economic community (May 1999 Fourth Summit). The Union of the Arab Maghreb (AMU) had no explicit mandate on peace and security in its Constitutive Treaty, but the objectives of the treaty include ensuring regional stability and enhancing policy coordination. In 2012 member states began developing strategies to combat terrorism and organised crime, and to enhance cooperation in the region (United Nations Economic Commission for Africa, 2013). To date, the AMU has not engaged in substantive conflict prevention and peacebuilding activities. While the goal of CEN-SAD is the creation of an open market and an area of freedom and solidarity, it has also instituted the Mechanism for Prevention, Management, and Resolution of the Conflicts (CENSAD Report, 2011).

In January 2012, the EAC adopted the Protocol on Peace and Security as well as the EAC Conflict Prevention, Management, and Resolution Mechanism. The EAC Peace and Security Protocol identified over 20 objectives for fostering regional peace and security, including combating terrorism and piracy; peace support operations; prevention of genocide; disaster management and crisis response; management of refugees; control of proliferation of small arms and light weapons; and combating transnational and cross-border crimes. The EAC Conflict Prevention, Management, and Resolution Mechanism also includes initiatives for the prevention of conflicts where early-warning systems are an integral part of the peace and security workings of EAC. The EAC infrastructure has yet to be tested.

The ECCAS Protocol of Peace and Security established the Security Council in Central Africa (COPAX). COPAX has three vital organs: the Commission for Defence and Security, the Central African Early Warning System, and the Central African Multinational Force. In furtherance of the COPAX Protocol and the Mutual Assistance Pact, FOMAC was established in February 2000 as ECCAS's multinational non-permanent standby force. In October 2009, ECCAS adopted the Protocol Relating to the Strategy to Secure ECCAS's Gulf of Guinea and the Declaration of the Heads of State and Government on Maritime Safety and Security to promote the regional maritime security in the Central African region in 2013. ECCAS has been active in efforts to restore order, stability, and security in the region. ECCAS was present in the CAR from 2008 to 2013 with the Peace Consolidation Mission in the CAR or MICOPAX (Meyer, 2015).

Of the 54 member states of the AU, $30^{9}$ belong to two of the eight AU-recognised RECs, ten ${ }^{10}$ are parties to three RECs, and 14 have obligations to only one of the eight AU-recognised RECs. ${ }^{11}$ Membership of multiple RECs was an initial hindrance to the attainment of peace on the continent. ECCAS, for example, is formed by states that are also members of the SADC, EAC, COMESA, and CEN-SAD. Over time, however, there has been increasing collaboration between RECs and the AU and between RECs within and across regions. In July 2008, the Multinational Force in the Central African Republic (established by CEMAC in 2002 to promote peace and security in the conflict-inflicted Central African 
Republic) was transferred to ECCAS, a parallel organisation within the region, and made a part of COPAX (Meyer, 2015). The General Secretariat of CEN-SAD has cooperation agreements with COMESA and ECOWAS on security, among other issues. The CEN-SAD Secretariat General and ECOWAS Commission are expected to invite each other, as observers, to their meetings (CENSAD Report, 2011). EAC, IGAD, COMESA, the European Union, and the Indian Ocean Commission established a regional action plan against piracy to ensure regional maritime security (United Nations Economic Commission for Africa, 2013). The AU recognises RECs as official representatives of regional associations of African states that have increasingly taken up prominent roles in conflict resolution and peace support operations. Admittedly, African RECs have different degrees of engagement and success in the peacekeeping and peacebuilding processes. The deepening economic and social crises in many African countries, as well as the frequency, intractability, and spill-over effects of violent conflicts, place massive moral obligations on the RECs to act. In the not-too-distant future, these developments might stimulate the emergence of new African international law.

Humanitarian intervention as a legal framework and a political tool used by the international community is still a controversial issue in world politics and has been criticised as a new form of imperialism by the global North to exploit the global South (Halistoprak, 2015). The principle of the sovereignty and territorial integrity of member states is central to the UN; how will it be reconciled with the exigencies of the principle of R2P as enshrined in the ECOWAS and AU conflict management frameworks? The differences in the approaches to the principle of $\mathrm{R} 2 \mathrm{P}$ adopted by these organisations could generate problems when logistics and resource constraints demand a handover by ECOWAS and/or the AU to the UN.

\section{Coordination among RECs, the $\mathrm{AU}$, and the UN}

A review of the legal instruments of the UN, the AU, and RECs shows the possibilities of coordination and cooperation on peacebuilding. In 2007, the UN General Assembly adopted resolution A/RES/61/296 on cooperation between the $\mathrm{UN}$ and the $\mathrm{AU}$, requesting the UN system to intensify its assistance to the $\mathrm{AU}$, especially in terms of putting into operation its PSC. The UN seconded a staff member to provide support for the AU's Panel of the Wise. Since 2008, the UN Secretariat and the AU Commission have progressively enhanced interaction with regular consultative meetings. On 1 July 2010, the General Assembly consolidated and upgraded UN's interface with the AU by creating the UN Office to the AU, headed by an Assistant Secretary-General. The office was formally inaugurated on 22 February 2011 and integrated the peace and security presences in Addis Ababa: the UN Liaison Office, the AU Peace and Support Team, the UN Planning Team for AMISOM, and the administrative functions of the Joint Support and Coordination Mechanism of the AU-UN Hybrid Operation in Darfur (Security Council Report, 2011). These culminated in the 2017 Joint UN-AU Framework for Enhanced Partnership in Peace and Security. The partnership between the UN Secretariat and AU Commission is underpinned by institutional 
mechanisms such as the Joint Task Force on Peace and Security, the UN-AU Annual Conference, the AU Permanent Observer Mission to the UN, and the UN Office to the AU. There is, on the one hand, the cordial working relationship between the UN Secretary-General and AU Commission Chairperson and, on the other hand, functional day-to-day working relationships between special envoys, focal points, and other staff. Cooperation on mediation is particularly advanced, and relationships on electoral support and the "Silencing the Guns" initiative are growing, but the partnership is weakest on peacebuilding and post-conflict reconstruction (Forti and Singh, 2019).

The founding document of the PBC envisaged a role for regional and subregional organisations in the work of the commission and anticipated that the $\mathrm{PBC}$ would serve as a vehicle to develop REC capacity in peacebuilding processes. The PBC is engaged in six IGAD and ECOWAS member states: Sierra Leone, Burundi, Guinea-Bissau, Liberia, the Central African Republic, and Guinea, with Sierra Leone and Burundi being the first two PBC focus countries. The experience has been that the approach to peacebuilding continues to be compartmentalised and the first decade of the PBC's existence has made minimal contributions to the peacebuilding capabilities of the regional and sub-regional organisations of the focus countries.

Effective global-regional partnership is possible through increased consultation, cooperation, and collaboration but the dominant actors must change their orientations and become more supportive of a regionalist approach in the pursuit of international security and peace (Adetula, 2015). The UN Security Council (UNSC) and the AU Peace and Security Council (AUPSC) relationship has been quite dynamic to say the least. The case of Côte d'Ivoire was revealing in some respects. African states were generally uncomfortable with the way UN and French forces carried out the military operations that resulted in the arrest of President Laurent Gbagbo. Both the chair of the AU and Thabo Mbeki, former President of South Africa and AU mediator for Côte d'Ivoire, declared the military intervention as unjustified. For Mbeki, what happened in Côte d'Ivoire was simply "the UN entrenching former colonial powers on our continent" (Mbeki, 2011). UN Secretary-General Ban Ki-moon defended the UN intervention, claiming that the forces acted strictly within the framework of the responsibility to protect (R2P), based on UNSC Resolution 1975 of 30 March 2011 (Schori, 2015).

The case of Libya demonstrated how a lack of consultation could hamper the development and consolidation of a global-regional partnership on peace. The $\mathrm{UN}$ and $\mathrm{AU}$ had different perceptions and interpretations of the issues involved in the conflict, and made no effort to coordinate their conflict-resolution strategies. Ultimately, the AU felt deliberately side-lined and this was interpreted as a conspiracy to ignore African efforts to resolve the conflict. The response to the military coup in Guinea-Bissau also pitched the AU, European Union (EU), and the UN against ECOWAS, whose mediation resulted in the setting up of a transitional government that the other organisations would not recognise (Adetula, 2015). The indications are that the AU wants to be recognised as the leading regional organ for collective security in Africa. This may bring the AU into a confrontation with 
the UN Security Council, which does not appear prepared to cede its mandate of maintaining global peace and security to regional organisations (Bam, 2012, 8). Additionally, the UN's post-conflict peacekeeping approach, which requires a ceasefire agreement and prior consent of parties to the conflict, does not lend itself easily to the realities of African conflicts, as was experienced in Rwanda, Darfur, and Somalia (Adetula, 2015). Article 4 (h) of the Constitutive Act gives the AU the right to intervene in a member state according to "a decision of the Assembly in respect of grave circumstances, namely war crimes, genocide and crimes against humanity." These provisions give the AU a right of access to theatres of conflict that other external actors do not have. The AU is also uniquely enabled to implement strategies for the prevention of violent conflicts. It is a radical departure from the principle of non-interference embodied in the United Nations Charter.

Other areas of growing tension that may impact continuous cooperation between African countries and the UN system include the unrepresentativeness of the UN Security Council and the misuse of prosecutorial discretion at the International Criminal Court (ICC). Further to UN Security Council (UNSC) Resolutions 1593 (2005) and 1970 (2011), arrest warrants were issued for Omar Al Bashir, Sudan's Head of State, in 2009 for war crimes and crimes against humanity and in 2010 for genocide, and Muammar Gaddafi, the Head of State of Libya, in 2011 for crimes against humanity. The AU passed a resolution of non-cooperation with respect to the arrest warrants. The ICC filed findings of non-compliance against the African states that received the Heads of States. In rejecting the ICC's findings of non-compliance, the AU reaffirmed that by receiving President Bashir, the Republic of Chad, Kenya, and Djibouti were discharging their obligations under Article 23 of the Constitutive Act of the African Union and Article 98 of the Rome Statute as well as acting in pursuit of peace and stability in their respective regions (African Union, 2011). The tipping point was when the prosecutor filed charges against the President and Vice President of Kenya. The AU condemned the move and fiercely asserted immunity for all serving Heads of State on the continent (African Union, 2013).

African leaders have sought to address some of the asymmetries in UN-Africa relations by demanding for the reform of the security council by making it more representative of all regions of the world. However, the resistance of the permanent members of the Security Council to demands for the restructuring exemplifies the desire for the preservation of the status quo by the P5 that dominates the UNSC, and by extension the architecture of global security (Adetula, 2015). It should, however, be acknowledged that concerted continuous efforts have been made to streamline and enhance the effectiveness of international peacebuilding processes.

\section{Conclusion and lessons learned}

Regional economic communities, particularly the AU, have been increasingly involved with the maintenance of international peace and security. This represents 
a renewed commitment of African states to the regionalist approach to peace and security. However, while the dominant international relations discourse in the post-Cold War era acknowledges complex interdependence as one of the defining characteristics of the global system and tends to favour the regionalist approach in the management of inter-state relations, states are still generally protective of their sovereignty despite the overwhelming impact of globalisation processes (Jaiyebo and Adetula, 2013).

African regional organisations have made appreciable progress in ensuring peace and security in Africa. In 2017, African continental and regional organisations deployed seven multilateral peace operations on the continent (SIPRI, 2018 , 107). Each of these operations had its own success stories and challenges. Some of the main lessons include the need to strengthen the legal and institutional frameworks for regional collective peace and security systems, clarify roles, and guide the harmonisation of existing strategies and programmes. International regulations, such as the requirement of a formal invitation in the case of the United Nations and the rule of engagement that peace troops must remain neutral and only exercise a minimum of violence, limit the effectiveness of multilateral peace operations and need to be reviewed.

The interface of sovereignty with peacebuilding interventions by external actors is a slippery terrain. Peacekeepers and other personnel deployed to provide essential services in the conflict zones sometimes have to relate to the population in much the same way that governmental actors do within a country. This becomes a critical consideration with transitional administration, where the international operation acts as a state (Zwanenburg, 2004). With governmental functions upheld only with the assistance of external actors, pragmatism drives questions of sovereignty to the rear. The government is in a state of extreme vulnerability and the only restraint on external actors is their sense of self-restraint. The vital question of how to ensure accountability at all levels must be attended to.

There is considerable clarity in international law on the responsibility of the state for its actions, for the actions of organs acting on its behalf, including international organisations, and for the actions of organs of other states placed at its disposal. Article 6 of the International Law Commission Draft Articles on State Responsibility (Draft Articles) provides that the conduct of an organ placed at the disposal of a state by another state shall be considered an act of the former under international law if the organ is acting in the exercise of elements of the governmental authority of the state at whose disposal it is placed. ${ }^{12}$ Article 7 of the Draft Articles states that the conduct of an organ of a state or of a person or entity empowered to exercise elements of the governmental authority shall be considered an act of the state under international law if the organ, person, or entity acts in that capacity, even if it exceeds its authority or contravenes instructions. Within the context of peacebuilding, the host state bears residual responsibility for the actions of the entire peacebuilding team. For the avoidance of all doubts, Article 8 of the Draft Articles states that the conduct of a person or group of persons shall be considered an act of a state under international law if the person or group of persons is acting on the instructions of, or under the direction or control 
of, that state in carrying out the conduct. The direct responsibility of international organisations in international law is in its formative stages. The Drafting Committee of the International Law Commission has considered Draft Articles on Responsibility of International organisations. See UN Doc. A/CN.4/L.632 of 4 June 2003. ${ }^{13}$

The responsibilities of private companies and consultants for illegal acts committed in the course of peacebuilding are also becoming clearer. Unlike international responsibility, which is legal, the accountability of international organisations can present itself in different forms: legal, political, administrative, or financial (Zwanenburg, 2004). The accountability of international organisations is said to comprise three interrelated and mutually supportive components: (i) the extent to which international organisations, in the fulfillment of their responsibilities as established in their constituent instruments, are and should be subject to or exercise forms of internal and external scrutiny and monitoring, irrespective of potential and subsequent liability and responsibility; (ii) tortious liability for injurious consequences arising out of acts or omissions not involving a breach of any rule or norm of international and institutional law (e.g., environmental damage as a result of lawful nuclear or space activities); and (iii) responsibility arising out of acts or omissions which constitute a breach of a rule or norm of international and institutional law (International Law Association, 1998). Since the 1965 agreement between the United Nations and Belgium relating to the settlement of claims filed against the United Nations in the Congo by Belgian nationals, ${ }^{14}$ the United Nations has developed protocols for when and how claims can be made against it for wrongs committed in the course of its mission. ${ }^{15}$

The AU under APSA has the mandate to "develop policies and action required to ensure that any external initiative in the field of peace and security on the continent takes place within the framework of AU's objectives and priorities." The critical point to note is the supranational legal implication of these policies. In terms of effective oversight and discipline of peacebuilding personnel, the policies will affect the national law of the host state that is enforceable within the legal system of the host state or the community legal framework. The international mechanisms and protocols regulating the liabilities of continental and regional organisations in peacebuilding on the African continent have barely been tested.

Closely related is the involvement of civil society in peacebuilding activities. The African Charter for Popular Participation in Development and Transformation (Arusha Declaration) characterises Africa as having an "over-centralisation of power and impediments to the effective participation of the overwhelming majority [in decisions regarding] social, political, and economic development" and calls for "the full and effective participation of the people in charting their development policies, programs, and processes" (UNECA, 2016b). Both AU and ECOWAS peace and security infrastructure make liberal accommodation for civil society organisations. Article 20 of the PSC protocol gives a broad role to civil society in supporting the work of the PSC. Civil society organisations accredited to the AU's Economic Social and Cultural Commission can submit 
reports to the PSC via the AU Commission, provide information to AU field missions, and address the PSC on invitation. Civil society involvement helps to bring a broad range of social and political interests to the negotiating table, making the process more inclusive and participatory. However, if governance above the level of the nation-state is to be legitimate in a democratic era, mechanisms for appropriate accountability need to be institutionalised (Grant and Keohane, 2005).

Other challenges include the lack of adequate resources. Peace operations are costly, and the AU and RECs lack adequate financial resources for effective interventions. In the case of the AU, there are three sources of funding generally: ordinary budget funds, voluntary contributions from member states, and other sources, notably support from international donors and partners. Operationalising APSA has mainly been dependent on partner support. This has severe implications for sustainability, predictability, and flexibility. The AU budget faces arrears in contributions. In the past, rich and powerful countries, notably Algeria, Angola, Kenya, Nigeria, and South Africa, contributed a significant proportion of the AU budget.

Dependence on external funding for peacebuilding interventions by the AU and RECs may compromise the integrity, legitimacy, and ownership of the peacebuilding processes. In 2012, the AU Commission chairperson, Nkosazana Dlamini Zuma, pushed for a more self-sufficient AU to end the dependence on external funding. The proposed recommendations by the AU Reform Committee, which include the establishment of the jointly financed peace fund and reform in the areas of $\mathrm{AU}$ administration, infrastructures, and logistics, represent positive developments.

Peace and security are inextricably linked to development. The slogan "African solutions to African problems" should be applied to financing peacebuilding initiatives from within the continent. The legal frameworks favour African RECs as first responders to trouble spots on the continent but the resources to actualise the lofty ideals must be readily available.

\section{Notes}

1 Article 7(b) of S/RES/1645 (20 December 2005), and Article 7(b) of A/RES/60/180 (30 December 2005) provide for the participation of regional and sub-regional organisations in the PBC.

2 African Union Policyon Post Conflict Reconstruction and Development (2006), paragraph 8 .

3 See Assembly/AU/Dec.112 (VII) Doc. EX.CL/278 (IX)

4 For example, the ECCAS protocol establishing COPAX was formally ratified in January 2004 to include defense and security mechanisms aligned with the African Union's Peace and Security Architecture. Also the ECOWAS ECPF is consistent with the AU's Policy on Post-Conflict Reconstruction and Development.

5 ECOWAS Regulation MSC/REG.1/01/08.

6 ECOWAS Conflict Prevention Framework, para. 42. The 14 components are: earlywarning; preventive diplomacy; democracy and political governance; human rights and the rule of law; media; natural resource governance; cross-border initiatives; security governance; practical disarmament; women, peace, and security; youth empowerment; 


\section{Olugbemi Jaiyebo and Victor Adetula}

the ECOWAS Standby Force (ESF); humanitarian assistance; and peace education (the Culture of Peace).

7 Preamble to the Agreement Establishing the Intergovernmental Authority on Development (IGAD) (1986).

8 Article 3(d) of the treaty establishing COMESA.

9 Benin, Burkina Faso, Central African Republic, Chad, Cote d'Ivoire, Egypt, Ethiopia, Gambia, Ghana, Guinea-Bissau, Libya, Madagascar, Malawi, Mali, Mauritania, Mauritius, Morocco, Namibia, Niger, Nigeria, Senegal, Seychelles, Sierra Leone, South Sudan, Kingdom of Swaziland, Tanzania, Togo, Tunisia, Zambia, and Zimbabwe.

10 Angola, Burundi, Comoros, the Democratic Republic of Congo, Djibouti, Eritrea, Kenya, Rwanda, Sudan, and Uganda.

11 Algeria, Botswana, Cabo Verde, Cameroon, Congo, Equatorial Guinea, Gabon, Guinea, the Kingdom of Lesotho, Liberia, Mozambique, Sao Tome and Principe, Somalia, and South Africa.

12 Article 4 (1) of the International Law Commission Draft Articles on State Responsibility states that the conduct of any state organ shall be considered an act of that state under international law, whether the organ exercises legislative, executive, judicial, or any other functions, whatever position it holds in the organisation of the state, and whatever its character as an organ of the central government or of a territorial unit of the state. Article 6 provides that the conduct of an organ placed at the disposal of a state by another state shall be considered an act of the former under international law if the organ is acting in the exercise of elements of the governmental authority of the state at whose disposal it is placed.

13 The Drafting Committee of the International Law Commission considered Draft Articles on Responsibility of International Organisations. See UN Doc. A/CN.4/L.632 of 4 June 2003.

14 Agreement between the United Nations and Belgium relating to the settlement of claims filed against the United Nations in the Congo by Belgian nationals of 20 February 1965, 535 UNTS 199.

15 The UN Status of Forces Agreements are always explicit on these issues. See also the Report of the Secretary-General on the Financing of the United Nations Protection Force, the United Nations Confidence Restoration Operation in Croatia, the United Nations Preventive Deployment Force, and the United Nations Peace Forces headquarters; administrative and budgetary aspects of the financing of the United Nations peacekeeping operations: financing of the United Nations peacekeeping operations of 20 September 1996, UN Doc. A/51/389.

\section{References}

Adetula, V. (2015). African Conflicts, Development, and Regional Organisations in the Post-Cold War International System, Current Issues 61. Uppsala: Nordiska Afrikainstitutet Uppsala.

African Union. (2011). Decision on the Implementation of the Assembly Decisions on the International Criminal Court (ICC), 30 June-1 July 2011, AU Doc. Assembly/AU/Dec. 366(XVII), paras. 5-6.

African Union. (2013). Assembly, 'Decision on Africa's Relationship with the International Criminal Court', 12 October 2013, AU Doc. Ext/Assembly/AU/Dec.1 (Oct. 2013), paras. 10.1 .

Arcila, L. (2007). Occupation Law: (Mis)Use and Consequences in Iraq. Revista de Derecho y Economia, no. 21. Retrieved August 20, 2016 from http://190.7.110.123/ pdf/5_revistaContexto/Contexto/Archivo/Contexto\%2021/rev\%20contexto21.pdf\#pa $\mathrm{ge}=7 \overline{9}$ 
Bam, S. (2012). Foreword. In L. Gelot et al. (Eds.), Supporting African Peace Operations, Policy Dialogue, No. 8, pp. 8-9. Uppsala: Nordic Africa Institute.

ECOWAS. (2008). The ECOWAS Conflict Prevention Framework ECOWAS (MSC/ REG.1/01/08). Abuja, Nigeria. https://www.ecowas.int/

ECOWAS. (2016). Opening Remarks by the ECOWAS Commissioner for Political Affairs, Peace and Security Halima Ahmed (Mrs) at the Two-Day Sensitisation Workshop on August 29, 2016. Retrieved September 1, 2016 from www.ecowas.int

Forti and Singh. (2019). Toward a More Effective UN-AU Partnership on Conflict Prevention and Crisis Management, International Peace Institute and Institute for Security Studies, October 2019. https://www.ipinst.org/wp-content/uploads/2019/10/ 1910_UN-AU_Partnership-1.pdf

Francis, D. (2009). Peacekeeping in a Bad Neighbourhood: The Economic Community of West African States (ECOWAS) in Peace and Security in West Africa. African Journal on Conflict Resolution, 1(3), 87-116. doi: 10.4314/ajcr.v9i3.52180

Grant, R. \& Keohane, R. (2005). Accountability and Abuses in World Politics. American Political Science Review 99(1 February), 29-43.

Halistoprak, B. (2015). The Role of Regional Organisations in Humanitarian Intervention: The Case of Liberia Peacebuilding Operation and ECOWAS Intervention. Journal of Social Science and Humanities Research, Autumn, 35, 1-21. GUZ.

International Law Association. (1998). International Law Association Committee on Accountability of International Organisations, First Report 17 (1998).

Ismail, O. (2011). ECOWAS and Human Security. In T. Jaye, D. Garuba, \& S. Amadi (Eds.), ECOWAS and the Dynamics of Conflict and Peacebuilding. Dakar: Council for the Development of Social Science Research in Africa (CODESRIA), pp. 165-182.

Jaiyebo, O., \& Adetula, V. (2013). African Union and Its Supranational Institutions: Analysis, Opportunities and Challenges of the Pan-African Parliament. Nigerian Journal of International Affairs, 39 (3 September-December), 55-79.

Malebang, G. (2012). Peace Building and Security Policy in Southern Africa: The Case of the Southern African Development Community (SADC). Journal of Human Security Studies, 1, 50-68.

Mbeki, T. (2011). What the World Got Wrong in Côte D'Ivoire. Foreign Policy. https:/ /foreignpolicy.com/2011/04/29/what-the-world-got-wrong-in-cote-divoire/. Retrieved December 30, 2018.

Meyer, A. (2015). Preventing Conflict in Central Africa: ECCAS: Caught between Ambitions, Challenges and Realities. Central Africa Security Report, Issue 3. Institute for Security Studies.

Schori, P. (2015). ECOWAS and the AU in Cooperation with the UN: The Case of Côte d'Ivoire. In P. Wallensteen, \& A. Bjurner (Eds.), Regional Organisations and Peacemaking: Challengers to the UN. New York: Routledge, pp. 160-178.

Security Council Report. (2011, May 10). Working Together for Peace and Security in Africa: The Security Council and the AU Peace and Security Council (Special Research Report No. 2). Retrieved September 1, 2016 from http://www.securitycouncilreport.or $\mathrm{g} /$ special-research-report/

Stockholm International Peace Research Institute. (2018). SIPRI Yearbook 2018: Armaments, Disarmament and International Security. Oxford University Press.

United Nations. (1992). An Agenda for Peace: Preventive Diplomacy, Peacemaking, and Peace-Keeping(A/47/277-S/24111). New York. 


\section{Olugbemi Jaiyebo and Victor Adetula}

United Nations. (2015, June 29). The Challenge of Sustaining Peace. Report of the Advisory Group of Experts for the 2015 Review of the United Nations Peacebuilding Architecture (A/69/968-S/2015/490). New York.

United Nations Economic Commission for Africa. (2013). Report on Africa's Regional Integration Agenda. 2013 Eighth Session of the Committee on Trade, Regional Cooperation and Integration. Available from http://repository.uneca.org/bitstream/ha ndle/10855/22134/b10696118.pdf?s

Zwanenburg, M. (2004). Accountability under International Humanitarian Law for United Nations and North Atlantic Treaty Organization Peace Support Operations. Leiden: Leiden University, Open Access. 